\title{
Biochemical Genetic Confirmation of the Asexual Reproduction of Brooded Offspring in the Sea Anemone Actinia equina
}

\author{
J. Orr ${ }^{1}$, J. P. Thorpe ${ }^{1}$ and M. A. Carter ${ }^{2}$ \\ ' Department of Marine Biology, University of Liverpool, Marine Biological Station, Port Erin, Isle of Man, United Kingdom \\ ${ }^{2}$ Department of Biological Sciences, Portsmouth Polytechnic, King Henry I Street, Portsmouth, Hampshire, PO1 2DY, England
}

\begin{abstract}
The reproductive biology of the beadlet anemone Actinia equina $\mathrm{L}$. has been a topic of considerable research interest in recent years. Several theories have been put forward to explain the origin of young anemones found brooded in the enteron of female, male and apparently asexual individuals, but to date, conclusive evidence has not been produced to substantiate any of these hypotheses. In this paper, evidence is presented - based on the results of an investigation of isozymes from adult $A$. equina and their broods - which demonstrates that the young are asexually produced.
\end{abstract}

The sea anemone Actinia equina L. is extremely common on rocky shores throughout Europe (e. g. Stephenson, 1935; Manuel, 1981). As a result of its abundance and ecological importance the species has been extensively studied (e. g. Fischer-Piette, 1932; Crisp and Southward, 1958; Chia and Rostron, 1970; Schmidt, 1971; Francis, 1973; Ottaway and Kirby, 1975; Edmunds et al., 1976; Jones et al., 1977; Brace and Pavey, 1978; Rostron and Rostron, 1978; Brace et al., 1979; Carter and Thorp, 1979; Gashout and Ormond, 1979; Carter and Thorpe, 1981) and remains a subject of considerable research interest. Because of its ecological importance, it is essential that the reproductive strategy of the species is fully understood but, to date, there ist still great controversy concerning its mode of reproduction (c.f. Chia and Rostron, 1970; Cain, 1974; Rostron and Rostron, 1978; Carter and Thorp, 1979; Gashout and Ormond, 1979; Carter and Funnel, 1981).

It has long been known (Dalyell, 1848) that young anemones are brooded inside the enteron (gastric cavity) of an adult. More recent work (Chia and Rostron, 1970; Rostron and Rostron, 1978; Carter and Thorp. 1979; Gashout and Ormond, 1979) has shown that irrespective of sex, time of year or gonad condition, most adult Actinia equina will, under natural conditions, contain young anemones.

It has been proposed by Chia and Rostron (1970) that these young are derived from a sexually reproduced free swimming planula larva which metamorphosed to a young anemone only after seeking out and entering the eneteron of an adult. However, in a species which shows extensive colour polymorphism, it is difficult to reconcile this suggestion with the data of several authors (Cain, 1974; Carter and Thorp, 1979; Gashout and Ormond, 1979) showing that the brooded young are, at least generally, if not invariably, of the same colour as the parent.

Cain (1974) proposed 4 possible mechanisms to explain these various observations.

(1) Each colour variety (i.e. red, brown, green) may represent a different species.

(2) Planula larvae may re-enter and be brooded by adults of their own colouration only.

(3) A foster parent effect could control the colouration of the brooded offspring.

(4) The juveniles may be produced asexually or by parthenogenesis within the adult in which they are found.

In the light of subsequent work 3 of Cain's proposals can now be rejected.

(1) Recent studies (Orr, 1980; Haylor, 1981; Haylor et al., in preparation) have demonstrated that isoenzyme allele frequencies are randomly distributed between red and brown specimens, hence showing at least the red and brown colour morphs to be conspecific. (Green individuals, which were comparatively rare in the population, were not used in this study).

(2) Pre and post metamorphic larval forms will not reenter the enteron of an adult (Carter and Funnel, 1980). (3) Larval colour is stable in the laboratory both outside and within the enteron of a contrasting-coloured foster parent (Carter, in preparation)

Cain's fourth hypothesis, that asexual or parthenogenic reproduction could account for the brooded juveniles has not, to date been adequately tested. 
Another suggestion (Carter and Thorp, 1979) is that sexual reproduction is followed by post-fertilisational selection for genotypes similar or identical to that of the brooding parent. However, observations (Gashout and Ormond, 1979) that individuals maintained in total isolation in filtered or artificial seawater will continue to produce broods of young over periods of time indicate the probability of asexual reproduction. Self fertilisation cannot account for the majority of these broods since many authors (Chia and Rostron, 1970; Carter and Thorp, 1979; Gashout and Ormond, 1979) have concluded that Actinia equina is very infrequently if ever hermaphrodite.

Here we present data from isoenzyme studies which we consider demonstrate conclusively that the brooded young of Actinia equina are asexually produced. Specimens were obtained from a population at Fleshwick Bay, Isle of Man. Horizontal starch gel electrophoresis was used to screen these for 32 enzymes, of which 6 enzymes ( 7 loci) were found to be usefully polymorphic.

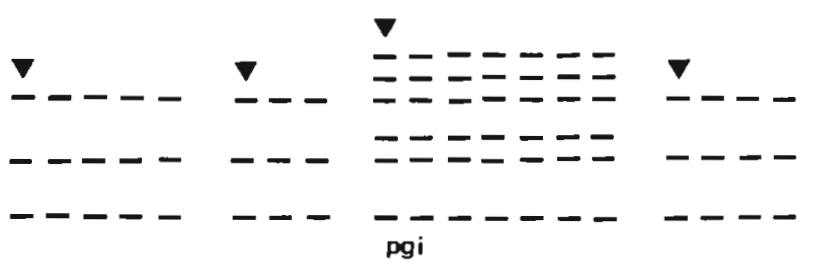

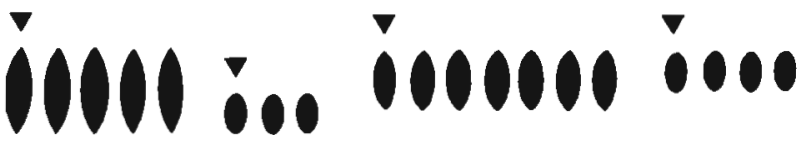

cat
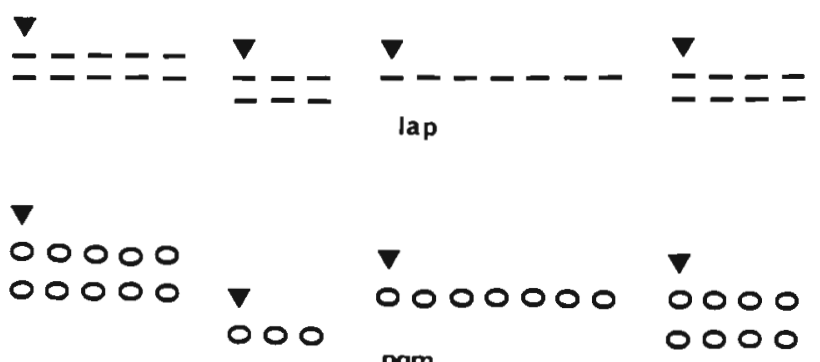

Fig. 1 Actinia equina. Electrophoretic banding patterns from parent and brooded young for 4 enzymes. In each parent/ brood group triangles denote parental tissue samples. The two-banded phenotypes for Lap and Pgm are interpreted as being heterozygotes at a single locus. For Pgi the banding patterns indicate the presence of 2 loci with a central hybrid zone (this is to be expected from the dimeric molecular structure of Pgi). The phenotype with 3 bands at the upper locus is considered to show heterozygosity at this locus with the expected 2 bands in the hybrid zone
Juveniles released from adult specimens were reared until they reached a size at which they could be used for electrophoresis. The broods of young anemones and adults were then compared by electrophoresis over 5 of the previously identified polymorphic enzyme loci (Fig. 1). It is clear that in every case the offspring are of identical genotype to the parent, although there is considerable genetic variation between broods

The results are essentially similar to those briefly described from investigations of the Australian Actinia tenebrosa (Ottaway and Kirby, 1975; Black and Johnson, 1979). It is likely therefore that in both species asexual reproduction is used to produce the brooded offspring. Self fertilization or inbreeding cannot account for the results since genetic segregation would be expected at least in the broods from heterozygous parents. The most likely mechanism for this is some form of budding in the enteron of the parent, although to date this has not been observed in histological studies (Chia and Rostron, 1970; Carter and Thorp, 1979; Gashout and Ormond, 1979). Gashout and Ormond (1979) suggested tentatively that somatic embryogenesis could account for the observations made on the reproduction of $A$. equina. They describe small pieces of tissue, sometimes resembling misshapen embryos, many of which were clearly derived from parts of the adult anemone. Gashout and Ormond (1979) also found that small pieces of adult tissue would, if cultivated in a Petri dish containing sea water, produce a membrane about themselves and swim by ciliary action. However, these authors failed to observe metamorphosis in vitro.

In the light of this work, and the demonstration by Polteva (1963) of somatic embryogenesis resulting from excision experiments with Actinia equina juveniles, it would appear possible that this mechanism could account for the production of the brooded young.

Such a mode of reproduction has not been previously described within the Anthozoa but budding and fragmentation are known to occur (reviewed by Chia, 1976). Somatic embryogenesis is therefore not a radical departure from previously described methods of asexual reproduction within the group

It should be noted that, although all the brooded young which we have examined were asexually reproduced, the presence of gonad in adult Actinia equina and of genetic variation at isozyme loci within the species (Orr, 1980; Carter and Thorpe, 1981; Haylor, 1981) provide clear evidence that sexual reproduction also occurs. Whether sexually reproduced offspring are ever brooded is not known; it is possible that they are released early in ontogeny as a dispersive phase of the life cycle. 


\section{LITERATURE CITED}

Black, R., Johnson, M. S. (1979). Asexual viviparity and population genetics of Actinia tenebrosa. Mar Biol. 53: 27-32

Brace, R. C., Pavey, J. (1978). Size dependent dominance hierarchy in the anemone Actinia equina. Nature, Lond 273: $752-753$

Brace, R. C., Pavey, J., Quicke, D. L. J. (1979). Intra-specific aggression in the colour morphs of the anemone Actinia equina: the 'convention' governing dominance ranking Anim. Behav. 27: 553-561

Cain, A. J. (1974). Breeding systems of a sessile animal. Nature, Lond. 247: 289-290

Carter, M. A. (in preparation). Gametogenesis and early development of two species of Actinia.

Carter, M. A., Funnel, M. (1980). Reproduction and brooding in Actinia. In: Targent, P., Targent, R. (eds.) Developmental and cellular biology of coelenterates. Elsevier/North Holland Biomedical Press, Amsterdam, pp. 17-22

Carter, M. A., Thorp, C. H. (1979). The reproduction of Actinia equina L. var. mesembryanthemum. J. mar. biol. Ass. U. K. 59: 975-1001

Carter, M. A., Thorpe, J. P. (1981). Reproductive, genetic and ecological evidence that Actinia equina var. mesembryanthemum and var. fragacea are not conspecific. J. mar. biol Ass. U. K. 61: 79-93.

Chia, F. S. (1976). Sea anemone reproduction: patterns and adaptive radiation. In: Mackie, G. O. (ed.) Coelenterate ecology and behaviour. Plenum Press, New York, pp. 261-270

Chia, F. S., Rostron, M. A. (1970). Some aspects of the reproductive biology of Actinia equina (Cnidaria:Anthozoa). J. mar. biol. Ass. U. K. 50: 253-264

Crisp, D. J., Southward, A. J. (1958). The distribution of intertidal organisms along the coasts of the English Channel. J. mar biol. Ass. U. K. 37: 157-208

Dalyell, J. G. (1848). Rare and remarkable animals of Scotland represented from living subjects: with Practical observations on their nature, Vol. 2, Van Voorst, London

Edmunds, M., Potts, G. W., Swinfen, R. C., Waters, V L. (1976). Defensive behaviour of sea anemones in response to predation by the opisthobranch mollusc Aeolidia papillosa (L.). J. mar biol. Ass. U. K. 56: 65-83

Fischer-Piette, E. (1932). Répartition des principales espèces fixés sur les les roches battus des côtes et des iles de la
Manche, de Lannion à Fécamp. Annls Inst. océanogr. Monaco 12: 107-213

Francis, L. (1973). Intra specific aggression and it affect on the distribution of Anthopleura elegantissima and some related sea anemones. Biol. Bull, mar. biol. Lab., Woods Hole 144: 73-92

Gashout, S. E., Ormond, R. F. G. (1979). Evidence for parth enogenic reproduction in the sea anemone Actinia equina. J. mar biol. Ass. U. K. 59: 975-987

Haylor, G. S. (1981). Genetic, morphological, behavioural and ecological evidence that Actinia equina green colour morphs are not conspecific with red and brown colour morphs. Unpublished thesis, University of Liverpool, Port Erin

Haylor, G. S., Thorpe, J. P., Carter, M. A. (in preparation) Genetic and ecological differentiation between sympatric colour morphs of the common intertidal sea anemone Actinia equina L.

Jones, W. C., Pickthall, V. S., Nesbitt, S. P (1977). A respiratory rhythm in sea anemones (Actinia and Metridium). J. exp. Biol. 68: 187-198

Manuel, R. L. (1981). British Anthozoa, Linnean Society of London, Synopsés of the British Fauna, Academic Press, London

Orr, J. (1980). An investigation into the method of reproduction of the beadlet anemone Actinia equina var. mesembryanthemum using horizontal starch gel electrophoresis. Unpublished thesis, University of Liverpool, Port Erin

Ottaway, J. R., Kirby, G. C. (1975). Genetic relationships between brooding and brooded Actinia tenebrosa. Nature, Lond. 255: 221-223

Polteva, D. G. (1963). Regeneration and somatic embryogenesis of Actinia equina in different stages of ontegenic development. Acta. biol. Hung. 14: 199-208

Rostron, M. A., Rostron, J. (1978). Fecundity and reproductive ecology of a natural population of Actinia equina (L.) (Cnidaria: Anthozoa). J. exp. mar. Biol. Ecol. 33: 251-259

Schmidt, H. (1971). Taxonomie, Verbreitung und Variabilität von Actinia equina Linné (Actiniaria: Anthozoa). Ztschrift. zool. Syst. Evol'forsch. 9: 161-169

Stephenson, T A. (1935). The British sea anemones, Vol. 2, Ray Society, London

Accepted for printing on October 5, 1981 